\title{
PRAWO DO STRAJKU GENERALNEGO. ROZWAŻANIA DE LEGE LATA I DE LEGE FERENDA
}

\begin{abstract}
The right to a general strike. Considerations de lege lata and de lege ferenda

The right to political (general, universal) strike is undoubtedly polycentric in nature, since in order to properly decode and interpret it, it is necessary to refer to both axiology, philosophy and national and international law, including EU law. Moreover, a political strike is in fact not only a result of axiological assumptions, accepted philosophical or doctrinal and political considerations. It manifests the state of the State and the level of democracy in terms of the struggle for the improvement of working and remuneration conditions, social sphere or public sphere.
\end{abstract}

Słowa kluczowe: prawo do strajku, strajk polityczny, prawo międzynarodowe, prawo unijne, międzynarodowa organizacja pracy

Keywords: right to strike, political strike, international law, EU law, international labour organisation

ASJC: 3308, JEL: K31

\section{Wstęp}

Obowiązująca w Polsce ustawa z dnia 23 maja 1991 roku o rozwiązywaniu sporów zbiorowych (Dz.U. 2020, poz. 123 tekst jedn. z dnia 27 stycznia 2020 roku, dalej: „ustawa o rozwiązywaniu sporów zbiorowych”, „u.spor.zbior.”) normatywnie nie przewiduje możliwości wytoczenia sporu zbiorowego, a w konsekwencji możliwości podjęcia tak zwanego strajku generalnego ${ }^{1}$ o charakterze powszechnym przez zatrudnionych przeciwko organom władzy państwowej czy samorządowej. Nie przewiduje zatem strajku generalnego osób wykonujących pracę zarobkową skierowanego przeciwko ogólnie pojętej władzy

1 Ustawa o rozwiązywaniu sporów zbiorowych nie posługuje się pojęciem sporu powszechnego, który - choć jakościowo różny - z konieczności należałoby traktować jako odmianę sporu wielozakładowego o zasięgu ogólnokrajowym (Cudowski 1998, s. 20). 
państwowej. Wynika to wprost $\mathrm{z}$ regulacji prawnej uznającej, że stroną sporu zbiorowego może być wyłącznie pracodawca (art. 1 u.spor.zbior.). Również z tego względu podjęcie strajku powszechnego przeciwko organom szeroko pojętej władzy państwowej nie ma charakteru akcji protestacyjnej w rozumieniu przywołanej ustawy. Niemniej powstaje istotna wątpliwość normatywna, a także - niewątpliwie - aksjologiczno-filozoficzna. Otóż czy uwzględniając prawo naturalne i podstawowe wartości z niego wynikające oraz regulacje międzynarodowego publicznego prawa pracy, a także prawa unijnego, w szczególności dotyczące sfery ochrony praw człowieka, podjęcie takiej akcji w Polsce jest $\mathrm{w}$ istocie nielegalne?

W przedmiotowym opracowaniu stawiam tezę, że - zarówno bazując na prawie pozytywnym, jak i mając podstawy konstrukcyjne wywodzące się z ochrony podstawowych wartości, w tym w szczególności z ochrony godności człowieka oraz naturalnego prawa do wyrażania niezadowolenia i oporu przeciwko niesprawiedliwości - strajk powszechny wszystkich ludzi pracy (a więc nie tylko pozostających w stosunku pracy) ${ }^{2}$ jest legalnym protestem.

\section{Rys historyczny strajku generalnego na ziemiach polskich}

Zjawisko strajku generalnego na terenie Polski ma w zasadzie tak samo długą historię (odnośnie do strajków powszechnych zob. np. Zieliński 1914) jak kształtowanie się ruchu walczącego o prawa pracownicze (pierwotnie określane prawami robotniczymi, prowadzonymi przez różnej orientacji ruchy społeczno-polityczne, od anarchistów czy socjalistów począwszy). Na ziemiach polskich (używam takiej terminologii z uwagi na okres zaborów) do wielkiego strajku o charakterze powszechnym - w postaci spontanicznego protestu - doszło już 28 stycznia 1905 roku. Akcja ta wzmocniona była wezwaniem do strajku przez partie polityczne - PPS oraz SDKPiL. Przyłączyło się do niego ponad 400 tysięcy osób. Później liczba protestujących wzrosła do ponad 1,3 miliona. W strajk włączyli się również uczniowie. W sumie w ciągu roku wybuchło blisko 7 tysięcy strajków. Ze względu na skalę zjawiska nie dziwi zatem, że wydarzenia te określa się także mianem rewolucji w Królestwie Kongresowym.

Należy także zauważyć, że z uwagi na charakter tych protestów (ich wymiar powszechny - obejmowały znaczny teren i wiele podmiotów zatrudniających) niejednokrotnie miały one bardzo krwawy przebieg. Przykładowo podczas protestów w Warszawie w ciągu kilku dni w starciach z armią carską śmierć poniosło blisko 100 strajkujących. Pochody z okazji Święta Pracy przyniosły kolejne ofiary, a symboliczny wymiar nabrała egzekucja 19-letniego Stefana Okrzei, którego oskarżono o próbę zamachu na oberpolicmajstra

2 Uprawnienie do udziału w strajku w rozumieniu ustawy o rozwiązywaniu sporów zbiorowych przez niepracowników wynika z nowelizacji ustawy z dnia 23 maja 1991 roku o związkach zawodowych (Dz.U. 2019, poz. 263 tekst jedn. z dnia 12 lutego 2019 roku), która dokonała także zmian w ustawie o rozwiązywaniu sporów zbiorowych i przyznała to prawo normatywnie także niepracownikom. 
Karla Nolkena, a następnie powieszono w warszawskiej Cytadeli. Równie gwałtowny przebieg miały wydarzenia w robotniczej Łodzi, gdzie strajk włókniarzy przeobraził się w wielodniowe starcia, a liczba zabitych i rannych wyniosła około 2000. Protesty w Łodzi stały się tak poważne, że car Mikołaj II zdecydował się wprowadzić w tym mieście stan wojenny. Do protestów i starć z rosyjskimi żołnierzami dochodziło również w Sosnowcu, Dąbrowie Górniczej, Ostrowie, Częstochowie, Radomiu i Kamiennej. W Kielcach miał miejsce strajk młodzieży gimnazjów (żeńskiego i męskiego). Strajki szkolne w całym Królestwie Polskim trwały jeszcze do 1908 roku. Wymienione protesty w Kongresówce wsparli Polacy z Galicji. Między innymi 2 lutego 1905 roku na krakowskim rynku miała miejsce manifestacja, w trakcie której Ignacy Daszyński podpalił portret cara Mikołaja II (Interia Historia 2015).

Strajki o charakterze powszechnym, tj. kierowane przeciwko ogólnie pojętym organom władzy, zdarzały się w Polsce także i później. Szczególnie mocno było to zauważalne w okresie PRL, kiedy miały miejsce pamiętne wydarzenia, jak poznański Czerwiec w 1956 roku, strajki w Trójmieście w 1970 roku czy te z 1976 roku w Radomiu i Ursusie. W konsekwencji te ruchy o charakterze de facto także społecznym w ostatnich dekadach XX wieku doprowadziły najpierw do ustanowienia demokratycznego ruchu związkowego w postaci podpisanych w 1980 roku porozumień gdańskich i jastrzębskich, a następnie pod koniec lat 80. - do upadku systemu politycznego, jakim był komunizm.

\section{Uwarunkowania normatywne prawa do strajku powszechnego w świetle regulacji prawa międzynarodowego}

Na wstępie należy wyraźnie zwrócić uwagę, że międzynarodowe publiczne prawo pracy nie zawiera, w postaci konwencji Międzynarodowej Organizacji Pracy (dalej: „MOP”), regulacji dotyczących wprost prawa do strajku zatrudnionych (Żołyński 2019b), choć pewne postanowienia się do niego odnoszą (o czym dalej). Przyczyna powyższego stanu faktycznego jest prosta - społeczność międzynarodowa in gremium uznała, że instytucjonalne unormowanie prawa do strajku przez międzynarodowe regulacje prawne w postaci stosownej konwencji MOP jest niemożliwe. Wynika to ze złożoności materii, a także uwarunkowań prawnych, kulturowych, społecznych czy środowiskowych różnych krajów świata. Różnice w poszczególnych systemach społeczno-politycznych oraz stopień rozwoju gospodarczego poszczególnych państw powodują, że trudno jest wypracować szczegółowe, a zarazem uniwersalne rozwiązania prawne dotyczące strajku, które byłyby akceptowalne przez wszystkie kraje. W tej materii należy zaznaczyć pewne kwestie.

Po pierwsze - uregulowania w zakresie prawa do strajku (bez określenia jego zakresu i sposobu prowadzenia) w aktach prawa międzynarodowego nie są jednolite, co wynika $\mathrm{z}$ tego, że pośrednio uprawnienie to zostało zawarte zarówno w aktach o charakterze powszechnym, jak również obejmującym jedynie pewien obszar świata. Ponadto niektóre akty prawa międzynarodowego odnoszą się do prawa do strajku wprost, inne zaś całkowicie go pomijają. W tej materii akty prawa międzynarodowego można zatem 
metodologicznie podzielić na dokumenty o charakterze uniwersalnym i regionalnym (Reda-Ciszewska 2015, s. 99-116).

\section{a) Uniwersalne}

Biorąc pod uwagę akty o charakterze uniwersalnym, należy przede wszystkim mieć na uwadze unormowania MOP.

- Jak wspomniano, prawo do strajku nie stało się wprost przedmiotem unormowania aktów prawnych tej organizacji. O prawie do strajku wspomina się jednak między innymi w kontekście wykładni art. 1 pkt d konwencji MOP nr 105, który ustanawia obowiązek zniesienia pracy przymusowej oraz zakaz korzystania z niej jako kary za udział w strajkach (konwencja nr 105 o zniesieniu pracy przymusowej, przyjęta w Genewie dnia 25 czerwca 1957 roku przez Konferencję Ogólną Międzynarodowej Organizacji Pracy, Dz.U. 1959, nr 39, poz. 240)33.W tym względzie należy wspomnieć także o konwencji MOP nr 151 odnoszącej się do osób zatrudnionych w służbie publicznej (konwencja nr 151 MOP dotycząca ochrony prawa organizowania się i procedury określania warunków zatrudnienia w służbie publicznej, przyjęta w Genewie dnia 27 czerwca 1978 roku, Dz.U. 1994, nr 22, poz. 78), w której pozwala się ustawodawcy krajowemu na wprowadzenie odstępstw w odniesieniu do osób zatrudnionych przez władze publiczne $\mathrm{w}$ zakresie, $\mathrm{w}$ jakim nie stosuje się do nich korzystniejszych postanowień międzynarodowych konwencji dotyczących pracy (art. 1 ust. 1 oraz art. 2). Do tej kategorii osób zalicza pracowników na wysokich stanowiskach, których czynności z reguły wiąże się z tworzeniem polityki lub funkcjami kierowniczymi, albo pracowników, których obowiązki mają w wysokim stopniu poufny charakter (art. 1 ust. 1).

- W aspekcie międzynarodowego publicznego prawa pracy podstaw do wszczynania akcji protestacyjnych w postaci strajku należy poszukiwać w Konwencji MOP nr 87 z dnia 9 lipca 1948 roku, dotyczącej wolności związkowej i ochrony praw związkowych (Dz.U. 1958, nr 29, poz. 125), tj. w postanowieniach zawartych $\mathrm{w}$ art. 3, 8 i 10. Konwencja ta reguluje sferę wolności związkowych oraz ochrony praw związkowych. Wynika z niej, że organizacje pracowników mają prawo do swobodnego wybierania swych przedstawicieli, powoływania swego zarządu, działalności oraz układania swojego programu działania w celu popierania i ochrony interesów pracowników. Z tego też względu, choć nie wynika to wprost, w celu ochrony interesów pracowniczych związki zawodowe uprawnione są do wszczynania różnych postaci akcji protestacyjnych, ze strajkiem włącznie. Tym samym, w sposób pośredni, prawo do strajku uznane zostało przez MOP za legalny środek obrony interesów pracowniczych. W materii prawa do strajku (choć nie

3 O strajku wspomina także w punktach 4,6 oraz 7 zalecenie MOP nr 92 dotyczące dobrowolnego pojednawstwa i arbitrażu, które stanowi, że żadne postanowienie niniejszego zalecenia nie będzie mogło być rozumiane jako ograniczające w jakikolwiek sposób prawo do strajku. 
tylko) waga tej konwencji sprowadza się także do tego, że w razie zaistnienia kolizji pomiędzy dwoma umowami międzynarodowymi, o ile sama umowa tego nie przewiduje, należy dać pierwszeństwo przedmiotowej konwencji, gdyż MOP, jako podmiot wyspecjalizowany, reguluje wszechstronnie tematykę wolności związkowych (Florek 1988, s. 132).

- W ostateczności - rozpatrując międzynarodowe akty prawne o charakterze powszechnym - należy także odwołać się do konstytucji MOP (Dz.U. 1948, nr 43, poz. 308; przyjęta w deklaracji filadelfijskiej z dnia 10 maja 1944 roku dotyczącej celów i zadań MOP, poprawionej w dniu 9 października 1946 roku w Montrealu przez Konferencję Ogólną MOP). Dokument ten już w preambule stanowi: „(...) pokój powszechny i trwały może być zbudowany jedynie na zasadach sprawiedliwości społecznej”. Z tego zapisu wynika, że sprawiedliwość społeczna może być osiągnięta tylko legalnymi sposobami. Takim legalnym środkiem jest między innymi prawo do oporu w postaci akcji protestacyjnych, u podstaw których leży sprzeciw wobec niesprawiedliwości społecznej.

W następnej kolejności należy przywołać inne akty prawa międzynarodowego.

- Dosyć szczegółowa regulacja znalazła się w Międzynarodowym pakcie praw gospodarczych, społecznych i kulturalnych, otwartym do podpisu w Nowym Jorku dnia 19 grudnia 1966 roku (Dz.U. 1977, nr 38, poz. 169), który wprost przyznaje pracownikom prawo do strajku. Z art. 8 ust. 1 paktu wynika, że państwa będące stroną tego aktu zobowiązały się zapewnić:

a) prawo każdego do tworzenia i przystępowania do związków zawodowych według własnego wyboru, w celu popierania i ochrony swych interesów gospodarczych i społecznych, jedynie pod warunkiem przestrzegania przepisów statutowych danej organizacji; b) prawo związków zawodowych do zakładania krajowych federacji lub konfederacji oraz prawa tychże do tworzenia międzynarodowych organizacji związkowych lub do przystępowania do nich; c) prawo związków zawodowych do swobodnego wykonywania swej działalności, bez ograniczeń innych niż przewidziane w ustawie i konieczne w demokratycznym społeczeństwie w interesie bezpieczeństwa państwowego lub porządku publicznego albo dla ochrony praw i wolności innych osób.

W ostatnim punkcie w ust. 1 art. 8 paktu przewiduje się ponadto, że państwa zobowiązują się do zapewnienia prawa do strajku pod warunkiem, iż będzie ono wykonywane zgodnie z ustawodawstwem danego kraju. Warto dodać, że Międzynarodowy pakt praw obywatelskich i politycznych otwarty do podpisu w Nowym Jorku dnia 19 grudnia 1966 roku (Dz.U. 1977, nr 38, poz. 167) w art. 22 ust. 1 przewiduje jedynie prawo do swobodnego stowarzyszania się z innymi, włącznie z prawem do tworzenia i przystępowania do związków zawodowych w celu ochrony swych interesów, nie wspominając o prawie do strajku.

- Podstaw do poszukiwania prawa do strajku powszechnego należy poszukiwać w Karcie Narodów Zjednoczonych, zawartej w San Francisco dnia 26 czerwca 1945 roku. 
W rozdziale IX Międzynarodowa współpraca gospodarcza i społeczna w art. 55 stwierdza się, że ONZ popiera - w celu stabilizacji i dobrobytu - podniesienie stopy życiowej i pełne zatrudnienie, a także poszanowanie i przestrzeganie praw człowieka oraz podstawowych wolności dla wszystkich (Karta Narodów Zjednoczonych, Statut Międzynarodowego Trybunału Sprawiedliwości i Porozumienie ustanawiające Komisję Przygotowawczą Narodów Zjednoczonych, Dz.U. 1947, nr 23, poz. 90). Ponadto w art. 56 państwa członkowskie zobowiązały się współpracować zarówno indywidualnie, jak i zbiorowo w celu osiągnięcia celów wskazanych w art. 55. Skoro art. 55 odwołuje się do podniesienia między innymi stopy życiowej i nakazuje poszanowanie podstawowych wolności, a jedną z podstawowych wolności jest prawo do oporu przeciwko niesprawiedliwości w środowisku pracy, to pośrednio uznaje zatem prawo do strajku i innych akcji protestacyjnych.

- Następne należy zwrócić uwagę na postanowienia zawarte w Powszechnej deklaracji praw człowieka, przyjętej na III Sesji Zgromadzenia Ogólnego ONZ w Paryżu dnia 10 grudnia 1948 roku. Otóż w art. 23 ust. 4 uznano, że: „Każdy człowiek ma prawo do tworzenia związków zawodowych i do przystępowania do związków zawodowych dla ochrony swych interesów”. Przywołany artykuł ujmuje zatem zakres osób uprawnionych bardzo szeroko. Nie odnosi się jedynie do pracowników czy osób świadczących pracę, uznając wolność do zrzeszania się w związkach zawodowych jako należną każdemu człowiekowi. Organizacje związkowe mają być więc powołane do rzeczywistej ochrony interesów ich członków, a ponadto w świetle przepisów Powszechnej deklaracji praw człowieka należy nie tylko zapewnić swobodę w zakresie zrzeszania się w związki zawodowe, ale także nadać im uprawnienia, które pozwolą na realną ochronę zrzeszonych w nich ludzi (Grygiel-Kaleta 2012, s. 284). Stąd należy wywodzić, że są uprawnione do prowadzenia akcji protestacyjnych w imieniu zrzeszonych w nich członków w celu ochrony ich praw i interesów. Powyższe postanowienia dotyczące sfery prawa pracy stanowią wyraźne rozwinięcie i de facto doprecyzowanie art. 2 deklaracji, która nie pozostawia absolutnie żadnej wątpliwości co do charakteru praw człowieka. W art. 2 wyraźnie bowiem zadekretowano podstawowe wartości cywilizacyjne. Stwierdzono mianowicie, że:

Każdy człowiek posiada wszystkie prawa i wolności zawarte w niniejszej Deklaracji bez względu na jakiekolwiek różnice rasy, koloru, płci, języka, wyznania, poglądów politycznych i innych, narodowości, pochodzenia społecznego, majątku, urodzenia lub jakiegokolwiek innego stanu.

W przedmiotowych artykułach niezmiernie ważne jest użycie dwóch określeń: „każdy” - co oznacza, że wszyscy ludzie mają prawo do tworzenia związków zawodowych i przystępowania do nich bez ograniczeń, oraz „wszystkie prawa i wolności” - co obejmuje także prawo do oporu przeciwko niesprawiedliwości społecznej. Powszechna deklaracja praw człowieka jest wyrazem odpowiedzialności społeczności międzynarodowej, nie traktuje bowiem praw i wolności jako bytu absolutnego. Uznaje mianowicie, że w pewnych okolicznościach prawa i wolności mogą 
zostać ograniczone. Oznacza to, iż formułuje tak zwaną klauzulę społeczeństwa demokratycznego (Żołyński 2019a). Klauzula ta została wyrażona w art. 29 ust. 2 i sprowadza się do uznania, że:

W korzystaniu ze swych praw i wolności każdy człowiek podlega jedynie takim ograniczeniom, które są ustalone przez prawo wyłącznie w celu zapewnienia odpowiedniego uznania i poszanowania praw i wolności innych i w celu uczynienia zadość słusznym wymogom moralności, porządku publicznego i powszechnego dobrobytu demokratycznego społeczeństwa ${ }^{4}$.

- Analizując przedmiotowe zagadnienie, nie można zapominać o Konwencji o ochronie praw człowieka i podstawowych wolności sporządzonej w Rzymie dnia 4 listopada 1950 roku (Dz.U. 1993, nr 61, poz. 284 ze zm.). Otóż w art. 4 ust. 2 wyraźnie wskazuje się, że nikt nie może być zmuszany do świadczenia pracy przymusowej lub obowiązkowej.

\section{b) Regionalne}

W materii aktów prawnych o charakterze regionalnym należy w szczególności zwrócić uwagę na Europejską kartę społeczną sporządzoną w Turynie dnia 18 października 1961 roku (Dz.U. 1999, nr 8, poz. 67). Zgodnie z częścią I pkt 5 i 6, które następnie zostały rozwinięte w części II art. 5 i 6, wszyscy pracownicy mają prawo zrzeszania się w organizacjach w celu ochrony swoich interesów oraz prawo do rokowań zbiorowych. Ponadto zagwarantowano, że w przypadku konfliktu interesów pracownicy posiadają prawo do strajku, z zastrzeżeniem zobowiązań, jakie mogłyby wyniknąć z wcześniej zawartych układów zbiorowych pracy.

Prawo do strajku zostało zagwarantowane także w art. 28 Karty praw podstawowych Unii Europejskiej (Dz.Urz. UE C 2012, nr 326/391, dalej: „KPP”; zob. Wróbel 2019, komentarz do art. 28). Artykuł ten określa mianowicie zarówno prawo do rokowań,

4 W tym względzie można przykładowo wskazać, że w praktyce funkcjonują restrykcje w zakresie swobody koalicji funkcjonariuszy państwowych, które najczęściej sprowadzają się do ograniczeń $\mathrm{w}$ wyborze reprezentujących ich organizacji związkowych. $Z$ reguły rozwiązania legislacyjne ograniczają możliwość zrzeszania się wyłącznie w związku zawodowym danej kategorii pracowników, na przykład w związku zawodowym policjantów (tak zwana zasada monizmu związkowego). Jak zauważa Komitet Ekspertów do Spraw Stosowania Konwencji i Zaleceń MOP, wprowadzenie takiego wyłączenia ma na celu zapobieżenie wszelkim formom politycznego zaangażowania się przez członków związku sektora publicznego lub wręcz „odstraszenia” ich przed podejmowaniem akcji strajkowych. Zdaniem MOP zasada monizmu dopuszczalna jest jedynie w odniesieniu do organizacji najniższego szczebla oraz przy zastrzeżeniu, że organizacje te: a) nie są ograniczone do pracowników poszczególnego ministerstwa, departamentu czy służby oraz b) mogą przystępować do wybranych przez siebie federacji i konfederacji na zasadach obowiązujących pracowników sektora prywatnego. Za niedopuszczalny uznano jednakże wymóg obligatoryjnego zakładania różnych organizacji związkowych dla każdej kategorii urzędników publicznych. Jednocześnie MOP wyraźnie uznaje, że w świetle konwencji nr 87 możliwość zrzeszania się w związkach zawodowych przez osoby zatrudnione w administracji publicznej w żaden sposób nie przesądza kwestii ich prawa do strajku (Sękara 2008, s. 49-50). 
jak i do działań zbiorowych, w tym prawo do strajku pracownicy i pracodawcy, lub ich odpowiednie organizacje, mają, zgodnie z prawem Unii oraz ustawodawstwami i praktykami krajowymi, prawo do negocjowania i zawierania układów zbiorowych pracy na odpowiednich poziomach oraz do podejmowania w przypadkach konfliktu interesów działań zbiorowych, w tym strajku, w obronie swoich interesów. W tej materii należy zwrócić uwagę, że prawo do rokowań i działań zbiorowych określone w art. 28 KPP opiera się na bardziej ogólnym art. 6 Europejskiej karty społecznej (Dz.U. 1999, nr 8, poz. 67, dalej: „EKS”). Artykuł 6 jako pierwszy przepis prawa międzynarodowego przewidział możliwość strajku (Wróblewski 2014, s. 85). Jego treść wykracza także poza ochronę działań zbiorowych na poziomie państw członkowskich. Treść normatywna art. 6 EKS jest bogata w szczegóły, za to art. 28 KPP jest krótki i zwięzły. Zawiera on trzy odrębne prawa: prawo do rokowań zbiorowych, prawo do zawierania układów zbiorowych oraz prawo do działań zbiorowych, również strajków. Niemniej prawa te są ze sobą tematycznie i konstrukcyjnie powiązane.

Nie można także zapominać o Europejskiej konwencji praw człowieka (właśc. Konwencji o ochronie praw człowieka i podstawowych wolności, Dz.U. 1993, nr 61, poz. 284 ze zm.), która w art. 4 ust. 2 wyraźnie wskazuje, że nikt nie może być zmuszony do świadczenia pracy przymusowej lub obowiązkowej. Ponadto w art. 11 ust. 1 gwarantuje każdemu prawo do swobodnego pokojowego zgromadzenia się. Wolność tę Konwencja rozumie szeroko. Stąd między innymi Europejski Trybunał Praw Człowieka w jednym z orzeczeń wskazał, że:

(...) prawo do wolności zgromadzania się jest prawem fundamentalnym w społeczeństwie demokratycznym i podobnie jak wolność wypowiedzi stanowi jedną z jego podstaw. Nie może więc być interpretowane w sposób restrykcyjny. Prawo to jako takie obejmuje zarówno spotkania prywatne, jak i publiczne na głównych ulicach oraz spotkania statyczne i publiczne pochody.

Ponadto podkreślił, iż zgodnie z zasadą ogólną:

(...) każda demonstracja w miejscu publicznym nieuchronnie prowadzi do pewnego zakłócenia zwykłego życia, w tym ruchu drogowego. Władze publiczne powinny jednak wykazać pewien stopień tolerancji dla pokojowych zgromadzeń, jeśli wolność zagwarantowana przez art. 11 Konwencji nie ma być pozbawiona wszelkiej treści ${ }^{6}$.

Po drugie - w przypadku dokumentów, które nie mają charakteru stricte normatywnego, duże znaczenie w zakresie regulacji MOP mają wypowiedzi jej organów kontrolnych,

${ }^{5}$ Potrzeba stworzenia jednolitego katalogu praw i wolności chronionych w Unii pojawiła się wraz ze wskazaniem poszanowania praw człowieka jako zasady ogólnej prawa unijnego w orzecznictwie TSUE. Bezpośrednie prace, których efektem było przyjęcie jednolitego dokumentu Karty, rozpoczęły się na mocy decyzji o ujednoliceniu systemu ochrony praw człowieka, podjętej przez Radę Europejską podczas szczytu w Kolonii. Ostatecznie Karta podpisana została przez trzy instytucje: Radę, Komisję i PE w Nicei w 2000 roku (Krzysztofik 2014, s. 65).

6 Wyrok ETPC z dnia 26 listopada 2013 roku, skarga nr 37553/05. 
które niewątpliwie kształtują wykładnię publicznego międzynarodowego prawa pracy. W tej materii istotne jest między innymi stanowisko Komitetu Wolności Związkowej odnośnie prowadzenia strajków, w tym w szczególności strajków politycznych. Zdaniem Komitetu Wolności Związkowej (nr 528 i 529 Wolności związkowej) strajki czysto polityczne nie mieszczą się w zakresie materii związanej z zasadą wolności związkowej (Międzynarodowe Biuro Pracy 2012). Wskazano jednakże, że tak zwane strajki powszechne, ogólnokrajowe (generalne) są dopuszczalne, gdy jest to uzasadnione celami społeczno-gospodarczymi, a nie politycznymi. Co prawda, strajki te stanowią przejaw zakłóceń w życiu publicznym, którego organizacja w normalnie funkcjonującym państwie opiera się na odrębności dwóch układów - ekonomicznego ustroju pracy i ustroju politycznego, lecz w wyniku tego protestu pracownicy wyrażają swoją dezaprobatę dla panujących stosunków ustrojowo-politycznych, działalności organów władzy i administracji państwowej oraz partii politycznych. Stąd zalecenia MOP zaliczają do nich takie zagadnienia, jak na przykład żądanie podniesienia płacy minimalnej, respektowanie układów zbiorowych pracy, zmiana polityki gospodarczej (na przykład obniżenie cen i zmniejszenie bezrobocia), zmiana systemu podatkowego oraz systemu zabezpieczeń społecznych, gdyż wchodzą w zakres normalnej działalności związkowej (nr 543 Wolności związkowej). W konsekwencji uznanie takiego strajku za nielegalny stanowiłoby poważne pogwałcenie wolności związkowej (nr 541 i 542 Wolności związkowej). Pracownicy muszą mieć bowiem prawo do legalnego strajku, którego celem jest krytyka polityki społecznej i gospodarczej państwa ${ }^{7}$. Tym samym oznacza to, że instytucje MOP dopuszczają strajk o charakterze mieszanym (polityczno-społeczno-ekonomicznym).

W tym miejscu należy wyraźnie zaznaczyć, że do polskiego porządku prawnego nie zostały zaimplementowane zalecenia organów MOP dotyczące możliwości wszczynania strajków o charakterze polityczno-społeczno-ekonomicznym (mieszanym; Żołyński 2013), a więc i wszczynania sporów zbiorowych w celu ochrony szeroko rozumianych praw pracowniczych ${ }^{8}$, nie tylko tych, które przedmiotowo zostały wyszczególnione enumeratywnie w art. 4 u.spor.zbior. Brak przyjęcia powyższych zaleceń ma określone konsekwencje. Sytuacja ta niewątpliwie utrudnia łagodzenie nastrojów społecznych i zmusza związki zawodowe do poszukiwania porozumień z partiami politycznymi, co tym samym upolitycznia ten w istocie społeczny ruch, a w konsekwencji powoduje utratę podstawowego charakteru związków zawodowych - walki o dobro ludzi pracy. Organizacje te muszą wikłać się w układy partyjne, ważąc jedne interesy względem drugich, często występując przeciwko innym związkom zawodowym, rozbijając tym samym ten ruch społeczny w Polsce. Niejednokrotnie prowadzi to także do zakładania

Pogląd taki wyraził Komitet Ekspertów do Spraw Stosowania Konwencji i Zaleceń MOP (za: Świątkowski 2009, s. 26).

${ }^{8}$ Na marginesie niniejszych wywodów należy zwrócić uwagę, że w doktrynie polskiego prawa pracy istnieje powszechny pogląd o nielegalności protestacyjnych akcji strice politycznych prowadzonych przez związki zawodowe na terenie zakładu pracy (Cudowski 1998, s. 138; Baran 2001, 2002; Witkowski 2013). 
tak zwanych związków żółtych (Żołyński 2014, s. 94), które popierają politykę pracodawcy lub określonych sił politycznych.

\section{Uwarunkowania aksjologiczne i społeczne prawa do strajku powszechnego}

Przechodząc do analizy uprawniającej do uzasadnienia postawionej tezy o legalności akcji protestacyjnej zatrudnionych w postaci strajku powszechnego (generalnego), niezbędne jest odwołanie się do przestrzeni aksjologiczno-filozoficznej. Konieczność taką zauważali nawet niektórzy teoretycy prawa marksistowskiego, uznając, że prawo winno być $\mathrm{w}$ tej przestrzeni nośnikiem lub co najmniej potwierdzeniem jakichś wartości, a nie tylko produktem walki klas (Rozmaryn 1950, s. 6). Otóż prawo pracy, w tym w szczególności zbiorowe prawo pracy, w warstwie konstrukcyjnej bez wątpienia opiera się na wolności ${ }^{9}$ - wolności rozumianej jako niepodleganie niczyjej kompetencji. Wolność jest zatem swoistego rodzaju immunitetem, a więc uwolnieniem od obciążeń, niepodleganiem określonym przepisom. Bez wolności nie ma bowiem zbiorowego prawa pracy, gdyż brak wolności indywidualnej wyłącza wolność zbiorową. Jest to wolność związkowa w postaci swobody do zrzeszania się, której emanacją jest możliwość reprezentowania praw i interesów osób zrzeszonych, jak również osób niezrzeszonych ${ }^{10}$. Lecz jest to także wolność wyrażająca się w możliwości autonomicznego kształtowania własnych struktur organizacyjnych i powiązań między niezależnymi związkami zawodowymi. Jest to również niewątpliwie wolność w postaci prawa ${ }^{11}$ do sprzeciwu przeciwko niesprawiedliwości. Są to zatem wolności, które w obszarze praw związkowych i praw osób pozostających w zatrudnieniu należy rozpatrywać nierozłącznie. Ponadto są to także prawa naturalne, a więc nienadane, przyznane, nabyte w postaci prawa pozytywnego, gdyż wolności do zrzeszania się czy do oporu nie można ustanowić. Można jedynie zadekretować, unormować, uporządkowywać reguły formalne zrzeszania się (ramy organizacyjno-prawne) czy „organizacyjne” stosowania oporu. Prawa te mają bowiem charakter jednokierunkowy, gdyż wynikają z natury człowieka. Jednakże nie ma wolności idealnej, absolutnej, ponieważ bez pewnego ograniczenia wolności mielibyśmy do czynienia $\mathrm{z}$ anarchią. Regulacje publiczno-prawne mogą zatem ingerować $\mathrm{w}$ swoiście rozumiany zakres tych wolności, modyfikując przedmiot wolności, lecz wyłącznie ze względu na dobra wyższe, uwzględniając przy tym unijną i konstytucyjną zasadę proporcjonalności (na przykład interes ogółu, którego jedną z postaci jest bezpieczeństwo powszechne),

9 Prawo pracy ma charakter wybitnie wolnościowy, począwszy od nawiązania stosunku pracy, a na jego ustaniu skończywszy.

10 Używam pojęcia „osoby”, gdyż członkami związku zawodowego nie muszą być wyłącznie zatrudnieni.

11 Używam tutaj pojęcia „wolność” i „prawo” w znaczeniu sytuacji prawnej. Przyjmuję mianowicie, że w teorii prawa o prawach i wolnościach mówi się jako o sytuacjach prawnych jakiegoś podmiotu, pojętych jako pewne właściwości normatywne tego podmiotu, wyznaczone obowiązującymi normami prawnymi (Piechowiak 2003, s. 38). 
natomiast nie mogą w ogóle pozbawić wolności ludzi pracy. Należy też zwrócić uwagę na to, że regulacje MOP nie obligują do chronienia wszystkich i wszystkiego.

Prawo do oporu zbiorowego przeciwko niesprawiedliwości wynika z relacji indywidualnych; jednostkowego sprzeciwu przeciwko ogólnemu zjawisku zła. W warstwie psychologiczno-socjologicznej uprawnione jest zatem postawienie tezy, że prawo do oporu wynika z procesu zmian zachodzących w osobowości jednostki będących wpływem oddziaływania środowiska zewnętrznego kreującego powszechnie uznane pokrzywdzenie człowieka. Z tego względu w aspekcie aksjologicznym i filozoficznym uprawnienia do strajku powszechnego należy niewątpliwie poszukiwać w wartościach chronionych wywodzących się z prawa natury. Są nimi prawo do powszechnego szczęścia, zadowolenia, dobrobytu - zarówno materialnego, jak i niematerialnego (satysfakcji z życia), a także do powszechnej wolności, braku dyskryminacji, a zatem i oporu przeciwko niesprawiedliwości. Ponadto prawo do strajku należy postrzegać w kategorii dobra wspólnego (Żołyński 2016). Dlaczego właśnie w tej kategorii? Ponieważ prawo pozytywne winno wyrażać to, co jest ludziom potrzebne, a nie to, czego chcą. Rolą parlamentu i rządzących powołanych do tych funkcji w demokratycznych wyborach jest kierowanie się właśnie takim dobrem. Z tego względu prawo winno służyć wspomnianemu dobru wspólnemu. Instytucje prawne służące dobru wspólnemu nie pozostają jednak w sprzeczności z dobrem indywidualnym, dobrem konkretnej jednostki. Przeciwnie, dobro wspólne urealnia, upodmiotawia prawa jednostki. Dbając o dobro wspólne, dbamy tym samym o prawa jednostki. Dobro wspólne służy realizacji dobra jednostki, gdyż chroniąc to, co jest wspólne, chronimy pośrednio to, co jest ważne dla jednostki. Przykładem tego może być ochrona środowiska. Troszcząc się o nie, chronimy indywidualne dobro, jakim jest zdrowie i życie. Na gruncie prawa pracy będzie to także na przykład ochrona płac ogółu zatrudnionych w zakładzie pracy, gdyż chroniąc płace ogółu, chroni się wynagrodzenie jednostki. Może to być także zawieranie porozumień zbiorowych, jak układów zbiorowych pracy, których postanowienia normatywne „przechodzą" w uprawnienia indywidualne. Z tego względu dobro wspólne jest istotą funkcjonowania państwa, a zatem i funkcją prawa (Sobczyk 2017, s. 58).

Niezgodne z prawem naturalnym zachowania władzy - stanowiące, a raczej wprowadzające w życie prawa niesprawiedliwe (w sytuacji, gdy przyjmuje je parlament podporządkowany władzy wykonawczej), powszechnie nieakceptowalne, uważane za niesłuszne, sprzeczne z szeroko rozumianymi prawami człowieka - upoważniają nie tylko moralnie, lecz i normatywnie do nieposłuszeństwa obywatelskiego. Powstaje jednak kwestia, jak obywatele mają postępować wobec niejednokrotnie wręcz bandyckiego, amoralnego prawa. W obszarze aksjologiczno-filozoficznym oparcia, źródła prawa do strajku generalnego należy poszukiwać w regule lex iniustissima non est lex wypracowanej przez Gustava Radbrucha. Trzeba wyraźnie zaznaczyć, że wprawdzie reguła ta dotyczy systemu prawa legalnego, lecz łamiącego w drastyczny sposób zasadnicze, ugruntowane współcześnie ogólnoludzkie prawa moralne, jakimi są prawo do życia, równouprawnienie, zakaz dyskryminacji czy prawo do posiadania 
i ochrony własności prywatnej. Umożliwia ona tym samym w trybie nadzwyczajnym podważanie legalnych ustaw czy prawomocnych orzeczeń sądowych wydanych na podstawie takich aktów prawnych. Według Radbrucha przepisy prawa pozytywnego (lex) „rażąco, w najwyższym stopniu sprzeczne” z prawem naturalnym (ius) mogą i powinny być w procesie stosowania prawa traktowane tak, jakby w ogóle nie obowiązywały. Odwołanie się do prawa naturalnego i powszechnie obowiązujących moralnie norm prawnych pozwala rozpoznać i wyeliminować ustawowe bezprawie (z niem. Unrecht). Stanowi to zatem zaprzeczenie skrajnego pozytywizmu uznającego, że każda norma prawna, wydana przez odpowiedni organ państwowy, w odpowiedniej formie i w odpowiedni sposób jest zawsze częścią systemu prawa oraz ustanowionego porządku prawnego, a zatem jest normą bezwzglęnie obowiązującą.

$\mathrm{Z}$ tego też względu nie może funkcjonować w wymiarze moralnym państwo oparte wyłącznie na autorytecie siły. W takiej sytuacji powstaje bowiem karykatura wspólnoty ludzkiej zrzeszonej w organizacyjnej postaci państwa. Powstaje państwo prawa siły, a nie państwo uporządkowane, stabilne i mocne siłą stanowionego i - co niezmiernie istotne - egzekwowanego prawa. W prawie pozytywnym regulującym materię sporów zbiorowych nie można zatem zasłaniać się ogólnie pojętym bezpieczeństwem czy interesem państwa. Państwo to my - wszyscy jego obywatele. Stąd prawo musi wyrażać rozsądek, użyteczność i bezstronność. Również z tego względu usprawiedliwione jest prawo do wystąpień przeciwko niesprawiedliwej rzeczywistości. Prawo do oporu należy bowiem do dóbr podstawowych, którymi, parafrazując słowa Johna Rawlsa (2013, s. 12, 109-110), jest to, czego z założenia pragną racjonalne osoby, niezależnie od tego, czego pragną poza tym ${ }^{12}$. W konsekwencji prawo musi być sprawiedliwe, gdyż sprawiedliwość jest immanentną cechą instytucji państwa i samego społeczeństwa. Sprawiedliwość, czyli bezstronność zarówno formalna - w zakresie postępowań organów państwa wobec jednostki, jak i materialna - wyrażająca stałość w przyznawaniu należnego prawa jednostce.

Kończąc przedmiotowe rozważania, niewątpliwie należy także odwołać się do aspektu społecznego i prakseologicznego. W warstwie społecznej za prawem do strajku generalnego przemawia możliwość zawierania w jego wyniku porozumień społecznych. Porozumienie społeczne to nic innego jak dwustronna albo wielostronna umowa zawierana między władzami publicznymi a przedstawicielami pracowników lub/i pracodawców, określająca ogólne relacje w stosunkach pracy. W swej istocie ma ona charakter obligacyjny w tym znaczeniu, że wyznacza wzajemne zobowiązania jego stron oraz wzajemne granice tolerancji. Niemniej w sferze normatywnej nie rzutuje bezpośrednio na warunki zatrudnienia $\mathrm{w}$ indywidualnych stosunkach pracy. $\mathrm{Z}$ tego względu postanowienia tych porozumień nie mają charakteru roszczeniowego i nie mogą być skutecznie dochodzone na drodze sądowej (Baran 2010, s. 108).

12 Według Rawlsa dobrami podstawowymi są znajdujące się w dyspozycji społeczeństwa podstawowe prawa i wolności, władza i możliwości, czy dochód i bogactwo. 
Powyższe porozumienia posiadają zatem także przywoływane wcześniej uzasadnienie aksjologiczne. Porozumienia społeczne służą mianowicie ochronie wielu dóbr osób zatrudnionych, jak również dóbr obejmujących obszary społeczne (określenie wieku emerytalnego, partycypacja zatrudnionych w procesie prywatyzacji), obszary socjalne (wprowadzenie kryteriów podatkowych obniżających daniny płacone przez najmniej zarabiających, obowiązek tworzenia funduszu socjalnego przez pracodawców) czy obszary z zakresu bezpieczeństwa i higieny pracy (obligujące państwo do przyjęcia i wprowadzenia w życie dodatkowych regulacji publicznych zaostrzających przepisy dotyczące pracy w warunkach niebezpiecznych dla zatrudnionych; Żołyński 2021).

Porozumienia takie umożliwiają również kojarzenie żądań zatrudnionych z sytuacją społeczno-ekonomiczną kraju. Zapewniają mianowicie w obszarze gospodarczym i finansowym większą stabilność oraz ułatwiają uzyskanie akceptacji społecznej dla ogólnych założeń polityki gospodarczej państwa (Kieś 2013, s. 49). Z uwagi na to, że spory zbiorowe pracy mogą prowadzić wyłącznie związki zawodowe, wyznaczałoby to tym samym nowy podział ról i celów między z jednej strony państwem, a z drugiej strony partnerami społecznymi i pracodawcami.

Z kolei odnosząc się do wymiaru prakseologicznego, na wstępie przedmiotowych rozważań należy zauważyć, że u podstaw prakseologii jako nauki leży założenie, iż wszelkie działania podejmowane przez podmiot działający są po to, by ów podmiot osiągnął zamierzony przezeń stan rzeczy, czyli cel. Cel ten może być zewnętrzny wobec samego procesu działania - takie działanie nazywane jest działaniem heterotelicznym. Celem może być także samo wykonywanie czynności składających się na działanie - mowa wtedy o działaniu autotelicznym. Cele działań są stanami rzeczy wyróżnianymi pozytywnie przez podmiot działający ze względu na uznawane przezeń wartości (Gasparski 2019, s. 6).

Prakseologia niewątpliwie łączy się z racjonalnością. Z kolei kategoria racjonalności jest pojęciem wieloznacznym i stanowi przedmiot zainteresowania wielu dziedzin: szeroko pojętych nauk ekonomicznych (w tym zarządzania), socjologii, psychologii, filozofii, politologii czy prawa. Racjonalność mianowicie opisuje zachowania poszczególnych ludzi - oraz ich zbiorowości - z uwagi na aspekt diagnostyczny oraz interpretacyjny. Pozwala na definiowanie i porządkowanie rozmaitych zachowań społecznych, a w sensie normatywnym może także służyć do budowania rekomendacji, jak w określonej sytuacji postępować racjonalnie.

Jak wynika z przedstawionego wywodu, racjonalność może być badana z uwzględnieniem wielu aspektów, w tym także pod kątem określonej postawy aksjologicznej, filozoficznej czy konkretnej wizji świata (lub jej braku). W konsekwencji powoduje to, że niezbędne jest także odniesienie się do racjonalności aksjologicznej. Niemniej aksjologicznie racjonalne zachowanie nie powinno charakteryzować się wyłącznie efektywnością techniczno-ekonomiczną. Z tego względu podejmując decyzję, należy niewątpliwie uwzględnić całą sferę sensowności aksjologicznej w zakresie osiąganych celów oraz stosowanych środków. To powoduje, że należy dokonać rozróżnienia 
zarówno racjonalności celu, jak i środków oraz metod osiągania celu. W aspekcie aksjologiczno-prakseologicznym racjonalność celu oznacza to, co jest osiągalne. Można mówić o racjonalności celu także wtedy, gdy jest on podporządkowany realizacji konkretnej wartości. Z kolei racjonalność zastosowanych środków i podjętych decyzji jest wynikiem posiadanej wiedzy. Oznacza przyjęcie braku konieczności zanegowania wartości o wyższym znaczeniu od wartości samego celu (Gorynia 2021).

Przedstawiona powyżej argumentacja upoważnia do uznania, że w wymiarze prakseologicznym zasadności prawa do strajku generalnego należy upatrywać w przeciwwadze do spontanicznych akcji, które niejednokrotnie mogą przekształcić się w rozruchy uliczne. Efektem ich może być niszczenie mienia powszechnego $\mathrm{i}$ indywidualnego, a zatem niszczenie dorobku materialnego niekiedy całych pokoleń. Ponadto brak skanalizowania niezadowolenia społecznego w postaci możliwości udziału w legalnym proteście powszechnym może wpływać na sferę psychiczną społeczeństwa, powodującą różne stany chorobowe. To z kolei jest marnotrawieniem zgromadzonego potencjału finansowego w postaci składek na ubezpieczenie zdrowotne, które mogą być wykorzystane choćby na badania profilaktyczne, ograniczając tym samym ryzyko wystąpienia chorób cywilizacyjnych (badania „okresowe” na przykład w zakresie cukrzycy czy różnych postaci raka).

\section{Zakaz prawa do strajku politycznego a zasada proporcjonalności}

Analiza regulacji prawnych dotyczących prawa do strajku generalnego musi odwoływać się do fundamentów funkcjonowania państwa i prawa. Jedną z takich podwalin jest zasada proporcjonalności ${ }^{13}$, która ma zastosowanie do stanowienia prawa na poziomie Unii, jak i krajowym. Niemniej rozważania w tej materii byłyby niepełne i niespójne bez odwołania się do podstaw konstrukcyjnych zarówno prawa unijnego, jak i Konstytucji RP (Konstytucja Rzeczypospolitej Polskiej z dnia 2 kwietnia 1997 roku, Dz.U. 1997, nr 78, poz. 483 z dnia 16 lipca 1997 roku, dalej: „Konstytucja RP”). Otóż pomimo braku normy zarówno wprost zakazującej, jak i wprost uprawniającej do podjęcia takich strajków przeciwko - w umownym ujęciu - państwu czy organom władzy, to uznanie zakazu przeprowadzenia takiej postaci protestu społeczności zatrudnionych może pozostawać w sprzeczności z wykładnią prawa unijnego. Według orzecznictwa Trybunału

13 Na marginesie należy zwrócić uwagę, że przykładowo we Włoszech w orzeczeniu Sądu Konstytucyjnego z 1974 roku uznano, że - z punktu widzenia prawa karnego - tak zwany „czysty” strajk polityczny jest dozwolony. $\mathrm{W}$ wyroku tym zdefiniowano również pojęcie strajku politycznego. Uznano, że jest to strajk prowadzony w celach innych aniżeli ochrona praw ekonomicznych i socjalnych pracowników. Z kolei w wyroku Sądu Konstytucyjnego z 2004 roku rozpatrującego sprawę protestu przeciwko wysyłaniu włoskich żołnierzy do Kosowa uznano, że strajk polityczny jest również uprawniony z punktu widzenia prawa cywilnego. Odtąd wszelkie sankcje nakładane przez pracodawców na pracowników w związku z podejmowanym przez nich strajkiem uznawane są także za sprzeczne z przepisami zbiorowego prawa pracy (Franczak 2010, s. 233). 
Sprawiedliwości w Unii Europejskiej istnieje obowiązek wykładni prowspólnotowej. Stąd przez stosowanie prawa unijnego należy rozumieć także uwzględnianie całokształtu bogatej wykładni dokonywanej przez orzecznictwo Trybunału Sprawiedliwości. Wszystko to razem stanowi bowiem acquis communautaire (dorobek wspólnotowy) i z uwagi na obowiązywanie zasady praworządności, która to zasada ma charakter fundamentalny w systemie unijnym, musi być bezwzględnie przestrzegane przez wszystkie państwa członkowskie (Florek 2004, s. 2-8).

Istnieją dwie zasadnicze konsekwencje zasady proporcjonalności. Po pierwsze w prawie unijnym zasada proporcjonalności ${ }^{14}$ została wyrażona w art. 5 ust. 4 Traktatu o Unii Europejskiej (Dz.Urz. UE C 2012, nr 326/13). Przepis ten stanowi, że zgodnie z zasadą proporcjonalności zakres i forma działania Unii Europejskiej nie wykraczają poza to, co jest konieczne do osiągnięcia celów traktatów. Wskazuje się ponadto, że instytucje Unii Europejskiej stosują zasadę proporcjonalności zgodnie z Protokołem (nr 2) w sprawie stosowania zasad pomocniczości i proporcjonalności (Dz.Urz. UE C 2008, nr 115/206). W art. 5 tegoż protokołu zapisano, że możliwość lepszego osiągnięcia celu wspólnotowego na poziomie Unii Europejskiej uzasadnia się na podstawie wskaźników jakościowych, a tam, gdzie to możliwe - ilościowych. Podnosi się także, że w projektach aktów prawodawczych powinno się brać pod uwagę konieczność zminimalizowania wszelkich obciążeń finansowych lub administracyjnych nakładanych na Unię Europejską, rządy krajowe, władze regionalne lub lokalne, podmioty gospodarcze i obywateli, a także ocenić ich współmierność do zamierzonego celu. Wynika z tego również, że forma działania Unii Europejskiej powinna być możliwie najprostsza, służąca odpowiedniej realizacji celu i podporządkowana konieczności skutecznego wykonania. Unia Europejska powinna zatem wprowadzać regulacje jedynie w koniecznym zakresie. Osobno należy zwrócić uwagę, że według orzecznictwa Trybunału Sprawiedliwości w Unii Europejskiej istnieje obowiązek wykładni prowspólnotowej. Prawo krajowe należy zatem interpretować w duchu prawa wspólnotowego, to jest tak, aby prawo wewnętrzne w możliwie najszerszym zakresie odpowiadało regulacji wspólnotowej (Kurcz 2004, s. 197; Mitrus 2006, s. 364-374; Podgórska-Rakiel 2013, s. 238).

Po drugie - na gruncie krajowym zasadę proporcjonalności należy wywodzić wprost z Konstytucji RP. Pomimo że powszechnie przyjmuje się, iż zasada proporcjonalności wynika $\mathrm{z}$ art. 31 ust. 3, to jednak nie można jej - w moim przekonaniu - rozpatrywać bez odwołania się do art. 2. Zasada proporcjonalności jest bowiem konstrukcyjnie ważnym elementem składowym zasady demokratycznego państwa prawnego, wyrażonym w przytoczonym artykule, a tym samym komponentem zjawiska normatywnego i idei, jaką jest sprawiedliwość. Z tego względu idea proporcjonalności tworzy jedną z najważniejszych zasad prawa konstytucyjnego, co skutkuje uznaniem jej za metazasadę,

14 Zasada ta także nie wynika wprost z prawa międzynarodowego. Jest ona jednak dorozumiana z treści klauzul limitacyjnych, czyli przepisów ustanawiających warunki, które muszą być spełnione, aby ograniczenia praw i wolności mogły być uznane za zgodne z konstytucją lub umową międzynarodową zawierającą ich gwarancje (Śledzińska-Simon 2019, s. 23-24). 
a więc zasadę, która określa stosowanie innych zasad. Stanowi mianowicie skuteczną dyrektywę do rozstrzygania konfliktów między konkurującymi wartościami. W tym względzie stanowi element globalnego prawa konstytucyjnego. Jej wszechobecność jest także wynikiem filozoficznego zakorzenienia w Arystotelesowskiej idei złotego środka, nakazującej unikania skrajnych rozwiązań.

Zasada proporcjonalności sensu stricto (jako zakaz nadmiernej ingerencji) jest wyrazem reguły konieczności, której aplikacja wymaga wykazania, że badane przepisy są niezbędne dla ochrony dóbr wskazanych w art. 31 ust. 3 Konstytucji RP. Ponadto, że spośród środków skutecznie je chroniących wybrano środki najmniej uciążliwe, co wiąże się z rozważeniem przyjęcia możliwych środków alternatywnych i określeniem ich skuteczności. Zasada ta polega zatem na sprawdzeniu, czy efekty regulacji pozostają w odpowiedniej proporcji do nakładanych przez nią ciężarów, przy czym im bardziej cenna jest wartość naruszana i im wyższy stopień jej naruszenia, tym cenniejsza musi być wartość chroniona oraz wyższy stopień jej realizacji, z zastrzeżeniem, że w żadnym wypadku ustanowione ograniczenia nie mogą naruszać istoty wolności i praw (wyrok Trybunału Konstytucyjnego z dnia 5 czerwca 2014 roku, K 35/11, OTK ZU 2014, nr 6A, poz. 61). Oznacza zatem właściwe określenie praw i obowiązków, a także określenie właściwych korzyści społecznych. W tym też względzie stanowi element globalnego prawa konstytucyjnego. Państwo dobrze urządzone ( $\mathrm{z}$ ang. well-ordered) w zakresie unormowań publicznych to państwo, które dba o swoich obywateli. Wszystko to razem wzięte pod uwagę powoduje zatem, że państwo prawne opiera się na założeniu racjonalności prawodawcy, a warunkiem koniecznym realizacji tego założenia jest przestrzeganie proporcjonalności w procesie stanowienia prawa. Racjonalny prawodawca stanowi mianowicie prawo sprawiedliwe, stąd także w zasadzie sprawiedliwości należy upatrywać podstaw obowiązywania zasady proporcjonalności. Prawo nie jest bowiem stanowione dla wiary, lecz dla empirycznego poznawania. Dlaczego poznawania? Ponieważ funkcją prawa jest rozwiązywanie problematycznych stanów faktycznych, istotnych dla człowieka. Prawo nie może być kazuistyczne, a więc każda norma prawna winna być analizowana, interpretowana - a zatem poznawana - w odniesieniu do danego, odmiennego stanu faktycznego. Stąd w świecie prawa najważniejsze jest zbudowanie zaufania między obcymi sobie ludźmi.

Z powyższego wynika, że zasada proporcjonalności w szerokim ujęciu kładzie szczególny nacisk na adekwatność celu i środka użytego do jego osiągnięcia. $Z$ tego względu winna być zachowana zasada konieczności, której wdrożenie wymaga wykazania, że dane przepisy są niezbędne dla ochrony pewnych dóbr. Ponadto, że z spośród środków skutecznie je chroniących wybrano takie, które są najmniej uciążliwe czy inwazyjne. To z kolei wiąże się z potrzebą rozważenia możliwych do zastosowania środków alternatywnych oraz wyraźnym określeniem ich skuteczności. Przyjmowane akty prawne powinny bowiem realizować określony cel, nie ingerując i nie ograniczając nadmiernie praw podmiotowych, które zostały zawarte w Konstytucji RP. Stąd wynika, iż jeżeli cel pewnej regulacji prawnej można osiągnąć za pomocą dwóch środków, a jeden z nich $\mathrm{w}$ większym stopniu pogarsza sytuację prawną podmiotu, to należy wybrać ten drugi 
(orzeczenie Trybunału Konstytucyjnego z dnia 31 stycznia 1996 roku, K 9/95, OTK 1996, nr 1, poz. 2). Jak wskazuje Sławomira Wronkowska:

\begin{abstract}
W działalności organów prawodawczych (...) powinno się respektować tzw. wymaganie proporcjonalności (adekwatności); spośród możliwych (i zarazem legalnych) środków oddziaływania należałoby wybierać środki skuteczne dla osiągnięcia celów założonych, a zarazem możliwie najmniej uciążliwe dla podmiotów, wobec których mają być zastosowane, lub dolegliwe w stopniu nie większym, niż jest to niezbędne dla osiągnięcia założonego celu (Wronkowska 1995, s. 74).
\end{abstract}

Argumentacja ta - być może zbyt długa, lecz konieczna - ma istotne znaczenie w analizowanym problemie legalności strajku generalnego. Otóż zmusza do uznania, że instytucjonalna ingerencja w wolność w przestrzeni stosunków pracy - które są nie tylko stosunkami prawnymi, lecz także, a może w szczególności, stosunkami społecznymi, niezmiernie istotnymi relacjami zachodzącymi bezpośrednio pomiędzy ludźmi, a więc bezpośrednio dotyczącymi ludzi - winna być poprzedzana stosownym i wnikliwym dialogiem społecznym. Dialog społeczny może być prowadzony także w przypadku strajku powszechnego, czego dowodem są przywołane już porozumienia gdańskie czy jastrzębskie. Dialog społeczny jest mianowicie podstawą kształtowania wszystkich idei i właściwych realiów, realiów społecznych, gospodarczych oraz prawnych. Niemniej dialog społeczny wymaga instytucjonalnego wsparcia państwa, zwłaszcza w okresie przemian i kryzysów, które naruszałyby podstawy dotychczasowego ładu społecznego. Trzeba jednak pamiętać, że państwo, które w sposób wadliwy kształtuje ramy formalne dialogu społecznego, dopuszcza się „grzechu” utrudniania jego prowadzenia (Pisarczyk 2015, s. 77). Stąd dialog ten winien być prowadzony w sposób cywilizowany, w postaci sformalizowanych określonych przedstawicielstw społecznych. Odgórne narzucanie nieakceptowanych społecznie norm publicznych będzie prowadziło do zachowań aspołecznych, a tym samym będzie godziło w zasadę społecznej gospodarki rynkowej i demokratycznego państwa prawa. W konsekwencji uderzy w pokój społeczny. Wobec tego, co zostało zaprezentowane, niewątpliwie $\mathrm{w}$ warstwie normatywnej ograniczenie wolności - nie tylko w stosunkach pracy, lecz także we wszelkich stosunkach dotyczących zatrudnienia - musi być dokonywane bezwzględnie po przeprowadzeniu umownych konsultacji społecznych, ostatecznie przybierając formę prawną - postać ustawy. Niemniej efektywność takiego aktu prawnego będzie uzależniona także od pozaprawnego aspektu społecznego. Mianowicie od mandatu udzielonego władzy w powszechnych wyborach oraz od odpowiednio silnego poparcia i zaufania ze strony ogółu społeczeństwa, udzielonego z kolei partnerom społecznym.

Prawo krajowe należy zatem interpretować $\mathrm{w}$ duchu prawa wspólnotowego, to jest tak, aby prawo wewnętrzne w możliwie najszerszym zakresie odpowiadało regulacji wspólnotowej (Kurcz 2004, s. 197). Prawo krajowe należy także interpretować jednolicie w wymiarze międzynarodowego publicznego prawa pracy. Skoro na przykład zalecenia MOP dopuszczają akcje protestacyjne tego rodzaju, to w przypadku sporu państwa polskiego przed instytucjami MOP istnieje istotne zagrożenie uznania niezgodności 
prawa polskiego z szeroko rozumianymi regulacjami międzynarodowego prawa pracy.

\section{Strajk o charakterze powszechnym a jego koszty ponoszone przez pracodawce}

Poczynione w niniejszym opracowaniu rozważania byłyby niepełne bez co najmniej skrótowego przedstawienia następującego zagadnienia: czy pracodawca powinien ponosić koszty strajku o charakterze powszechnym? Mówiąc inaczej, czy pracodawca może ponosić konsekwencje finansowe braku świadczenia pracy przez strajkujących pracowników (lub innych zatrudnionych), pomimo że w przypadku strajku nie jest zobligowany do wypłaty wynagrodzenia? Odpowiedzieć na to pytanie pozwala nam aksjologia prawa. Należy odwołać się do wspólnoty i jej szeroko rozumianego dobrostanu, a więc do czegoś, co jest bliskie, ważne dla określonego kręgu ludzi. Wspólnotą jest zarówno pracodawca, jako w ostateczności konkretny człowiek/ludzie, przyobleczeni jedynie przez prawo $w$ różne formy organizacyjne, jak i zatrudnieni. Wspólnota wszystkich zatrudnionych, w tym atomistyczna wspólnota zakładu pracy, stanowi niewątpliwie szczególnego rodzaju kompozycję. Wspólnotowość jest mianowicie przejawem przenikającej się wzajemnej troski. W sferze prawa pracy wspólnotowość jest zasadniczo przejawem troski pracodawcy o byt materialny pracowników, a także pracowników o pracodawcę, w szczególności w obszarze ekonomiczno-gospodarczym. To wszystko stanowi także ekonomiczny wymiar prawa pracy.

Ponadto warto podkreślić, że należy odwołać się także do wspólnych wartości, jakimi w obszarze zatrudnienia są solidaryzm i bezpieczeństwo socjalne, które jest częścią bezpieczeństwa powszechnego. Skoro - według aktualnie obowiązującej regulacji - pracodawcy ponoszą w trakcie strajku koszty zabezpieczenia socjalnego, choćby w postaci konieczności wypłaty wynagrodzenia chorobowego w jego trakcie (art. 23 ust. 2 u. por. bior.), to tym bardziej ochrona dobra wspólnego wymaga stosownego zabezpieczenia w przypadku walki o ogólne prawa i interesy wszystkich zatrudnionych. Pracodawca zatem w imię wyższego dobra, jakim jest godność człowieka pracy, może w pewnych sytuacjach i przez pewien okres nie przysparzać sobie korzyści z pracy najemnej. Jest to zatem sfera normatywna, regulowana przepisami prawa publicznego. Prawo pracy jest prawem publicznym ${ }^{15}$, gdyż państwo swoimi uregulowaniami narzuca pracodawcy określone obowiązki i obciążenia, które ze swojej istoty należą do podstawowych obowiązków państwa.

$15 \mathrm{~W}$ prawie pracy elementów prywatnych jest stosunkowo niewiele. Sprowadzają się one generalnie do wolności w zakresie zawarcia stosunku pracy czy swobody wyboru - i to jedynie w pewnym zakresie rodzaju zawieranych umów. 


\section{Zakończenie}

Oczywiście w tak krótkim opracowaniu nie jest możliwe wyczerpujące rozwinięcie prezentowanego poglądu. Niniejsze rozważania można jednak podsumować, przedstawiając najważniejsze wnioski.

- Prawo do strajku politycznego (powszechnego, generalnego) ma niewątpliwie charakter policentryczny, gdyż do jego prawidłowego odkodowania i zinterpretowania konieczne jest odwołanie się zarówno do aksjologii, filozofii, jak i do prawa krajowego oraz międzynarodowego, w tym także do prawa unijnego. Ponadto strajk polityczny jest $\mathrm{w}$ istocie rzeczy nie tylko wypadkową założeń aksjologicznych, przyjętych rozważań filozoficznych czy doktrynalno-politycznych, lecz także przejawem stanu państwa i poziomu demokracji w przedmiocie walki o polepszenie warunków pracy i płacy, sfery socjalnej czy społecznej.

- Pomimo braku wyraźnej podstawy normatywnej na gruncie prawa polskiego kierowanie akcji protestacyjnych przeciwko organom władzy posiada wyraźne podstawy aksjologiczne i jest przez nie uzasadnione. Wynika to zarówno z praw człowieka $^{16}$, jak i z prawa naturalnego jako moralnego prawa do sprzeciwu przeciwko niesprawiedliwości. Prawo do godnego życia w wymiarze społeczno-ekonomicznym jest wyższą wartością niż szeroko rozumiany pokój społeczny w wymiarze bezpieczeństwa państwa. Dlatego naruszenie tego podstawowego prawa ludzkiego uprawnia do podjęcia strajku. Pokój społeczny nie może być zawsze priorytetem; wbrew temu, co próbowano społeczeństwu wmówić w czasach Polskiej Rzeczpospolitej Ludowej, nie może też mieć wymiaru ideologiczno-politycznego.

- Brak zakazu strajku powszechnego posiada istotne uwarunkowania prakseologiczne. Zakaz taki byłby sprzeczny z zasadą racjonalnego zachowania państwa w rozwiązywaniu problemów społecznych. Państwo winno w określonych sytuacjach umożliwić społeczeństwu legalne odreagowanie na istniejącą rzeczywistość i wręcz „wykrzyczenie” swojego niezadowolenia. Takie przyzwolenie może w efekcie pozwolić na zachowanie pokoju społecznego, ograniczając niszczenie mienia czy wywoływanie zamieszek. Strajk powszechny winien być instrumentem swoistego rozładowania napięć społeczno-gospodarczo-politycznych pomiędzy szeroko rozumianym kapitałem a pracą. W konsekwencji może skutkować zachowaniem pokoju społecznego w postaci braku niszczenia mienia czy wywoływania zamieszek zagrażających zdrowiu, a nawet życiu obywateli. Strajk o charakterze powszechnym jest bowiem formą gry konkurencyjnej między instytucjonalnym państwem a społeczeństwem.

16 Źródeł praw człowieka nie należy poszukiwać wyłącznie w obszarach prawa natury. Źródłem praw człowieka są też ogólne zasady prawa międzynarodowego. Do katalogu tych zasad ogólnych, odnoszących się bezpośrednio do praw człowieka, można zaliczyć: zasadę niedziałania prawa wstecz, zasadę wyłączenia od wyrokowania we własnej sprawie, zasadę ponoszenia odpowiedzialności karnej, zasadę naprawienia szkody, zasadę ochrony praw słusznie nabytych (nabytych w dobrej wierze), zakaz nadużywania praw, a także zasadę dobrej wiary, zasadę słuszności i zasadę sprawiedliwości (Masternak-Kubiak 2003, s. 52). 
- Zakaz prawa do strajku powszechnego na gruncie krajowym pozostaje w sprzeczności z wykładnią prawa międzynarodowego dokonywaną przez organy MOP. Zalecenia MOP dopuszczają takie akcje, a zatem, jak już wspomniano, w przypadku sporu państwa polskiego przed instytucjami MOP istnieje poważne zagrożenie uznania niezgodności prawa polskiego z szeroko rozumianymi regulacjami międzynarodowego prawa pracy.

- Niemniej - w celu usunięcia wątpliwości normatywnych na gruncie krajowym należałoby de lege ferenda przyjąć regulacje umożliwiające podjęcie akcji protestacyjnej w postaci strajku, wykraczającej poza ramy ustawy o rozwiązywaniu sporów zbiorowych. Wymagałoby to zatem uregulowania w formie ekstraordynaryjnej w postaci nowej ustawy lub na przykład możliwości wprowadzenia takiej akcji społecznej w ustawie z dnia 24 lipca 2015 roku o Radzie Dialogu Społecznego i innych instytucjach dialogu społecznego (Dz.U. 2018, poz. 2232 tekst jedn. z dnia 30 listopada 2018 roku). Jednocześnie jestem przeciwny przyjęciu takiego rozwiązania w obowiązującej ustawie o rozwiązywaniu sporów zbiorowych. Inna jest mianowicie płaszczyzna zakresu przedmiotowego sporu zbiorowego $z$ pracodawcą, a inna z organami państwa. Płaszczyzna sporu przeciwko organom władzy z zasady winna obejmować kwestie socjalno-społeczne, w co z kolei nie powinni być bezpośrednio wikłani pracodawcy.

\section{Bibliografia}

Baran K.W. (2001) Konstytucyjne aspekty wolności zwiazkowych, „Przegląd Sejmowy”, nr 6.

Baran K.W. (2002) Zbiorowe prawo pracy, Kraków.

Baran K.W. (2010) [w:] K.W. Baran, Ćwiertniak B.M., Dörre-Nowak D., Walczak K. (red.), Prawo pracy, Warszawa.

Cudowski B. (1998) Spory zbiorowe w polskim prawie pracy, Białystok.

Florek L. (1988) Podstawowe prawa człowieka [w:] L. Florek, M. Seweryński, Międzynarodowe prawo pracy, Warszawa 1988.

Florek L. (2004) Znaczenie wspólnotowego prawa pracy, „Praca i Zabezpieczenie Społeczne”, nr 5. Franczak K. (2010) Analiza stanowiska przedstawiciela Włoch - Giovanniego Orlandini dotyczacego wyroku Trybunału Sprawiedliwości Wspólnot Europejskich z siedzibą w Luksemburgu w sprawach Viking i Laval z grudnia 2007 roku, ,Studia z Zakresu Prawa Pracy i Polityki Społecznej", t. 17.

Gasparski W.W. (2019) Działania przedsiębiorcze a prakseologia i etyka, ,Prakseologia”, nr 161. Gorynia M. (2021) Racjonalność i pandemia, „Rzeczpospolita”, 28 kwietnia.

Grygiel-Kaleta Ż. (2012) Wolność zrzeszania się w związki zawodowe w aktach prawa międzynarodowego, „Roczniki Administracji i Prawa”, nr 12.

Grygiel-Kaleta Ż. (2015) Wolność zrzeszania się w zwiazkach zawodowych, Warszawa.

Interia Historia (2015) 27 stycznia 1905 r. Strajk powszechny w Królestwie Polskim, https:// historia.interia.pl/kartka-z-kalendarza/news-27-stycznia-1905-r-strajk-powszechny-w-krolestwie-polskim,nId,1596616 (dostęp: 8 października 2021). 
Kieś E. (2013) Porozumienia zbiorowe pogarszające warunki świadczenia pracy, praca doktorska, Katowice.

Kocot K., Wolfke K. (1976) Wybór dokumentów do nauki prawa międzynarodowego, Wrocław-Warszawa.

Krzysztofik E. (2014) Ochrona praw podstawowych w Unii Europejskiej po traktacie z Lizbony, „Roczniki Administracji i Prawa”, R. XIV.

Kurcz B. (2004) Dyrektywy wspólnoty europejskiej i ich implementacja do prawa krajowego, Kraków.

Masternak-Kubiak M. (2003) Przestrzeganie prawa międzynarodowego w świetle Konstytucji RP, Kraków.

Międzynarodowe Biuro Pracy (2012) Wolność związkowa. Przegląd podjętych decyzji i wprowadzonych zasad przez Komitet Wolności Związkowych Rady Administracyjnej MBP, Gdańsk.

Mitrus L. (2006) Wpływ regulacji wspólnotowych na polskie prawo pracy, Kraków.

Piechowiak M. (2003) Prawo a wolność. Prawa człowieka - Prawa rodziny [w:] R. Hliwa, A.N. Schulz (red.), 30 lat Poznańskiego Zakładu Instytutu Nauk Prawnych PAN, Poznań.

Pisarczyk Ł. (2015) Źródła prawa pracy z perspektywy 40 lat obowiązywania Kodeksu pracy [w:] A. Kosut, W. Perdeus (red.), Przemiany prawa pracy - od kodyfikacji do współczesności. Ksiega Jubileuszowa dedykowana Profesor Teresie Liszcz, „Studia Iuridica Lublinensia”, t. 24.

Podgórska-Rakiel E. (2013) Okres trwałości stosunku pracy działaczy związkowych w przypadku przejścia zakładu pracy na innego pracodawce,, ,Monitor Prawa Pracy”, nr 5.

Rawls J. (2013) Teoria sprawiedliwości, Warszawa.

Reda-Ciszewska A. (2015) Prawo do strajku w świetle konwencji o ochronie praw człowieka i podstawowych wolności, „Studia Prawno-Ekonomiczne”, t. 95.

Rozmaryn S. (1950) Prawo i państwo, Warszawa.

Sękara M. (2008) Wolność zrzeszania się w związkach zawodowych pracowników administracji publicznej w świetle prawa międzynarodowego, „Studia z Zakresu Prawa Pracy i Polityki Społecznej".

Sobczyk A. (2017) Państwo zakładów pracy, Warszawa.

Śledzińska-Simon A. (2019) Analiza proporcjonalności ograniczeń konstytucyjnych praw i wolności. Teoria i praktyka, Wrocław.

Świątkowski A.M. (2009) Ochrona praw człowieka w świetle przepisów prawa pracy i zabezpieczenia społecznego [w:] A.M. Świątkowski (red.), Ochrona praw człowieka w świetle przepisów prawa pracy i zabezpieczenia społecznego. Referaty i wystapienia zgłoszone na XVII Zjazd Katedr/ Zakładów Prawa Pracy i Zabezpieczenia Społecznego, Kraków 7-9 maja 2009 r., Warszawa.

Witkowski J. (2013) Problem akcji protestacyjnych o zabarwieniu politycznym, „Monitor Prawa Pracy", nr 9.

Wronkowska S. (1995) Zarys koncepcji państwa prawnego w polskiej literaturze politycznej i prawnej [w:] S. Wronkowska (red.), Polskie dyskusje o państwie prawa, Warszawa.

Wróbel A. (red.) (2019) Karta Praw Podstawowych Unii Europejskiej. Komentarz, Warszawa. Wróblewski M.(red.) (2014) Karta Praw Podstawowych Unii Europejskiej jako żywy instrument, Warszawa.

Zieliński J. (1914) Strajk powszechny, Paryż. 
Żołyński J. (2013) Strajk i inne rodzaje akcji protestacyjnych jako metody rozwiązywania sporów zbiorowych, Warszawa.

Żołyński J. (2014) Strajk i inne akcje protestacyjne w praktyce przedsiębiorstw [w:] J. Wranty (red.), Aktualne problemy reprezentacji pracowniczej w zbiorowych stosunkach pracy, Warszawa.

Żołyński J. (2016) Aksjologiczne, normatywne i społeczne podstawy prawa rozwiązywania sporów zbiorowych pracy, Gdańsk.

Żołyński J. (2019a) Klauzula społeczeństwa demokratycznego (obywatelskiego) w zbiorowym prawie pracy, „Studia z Zakresu Prawa Pracy i Polityki Społecznej”, t. 26, nr 1.

Żołyński J. (2019b) Prawo do akcji protestacyjnej pracowników. Mediacja i arbitraż [w:] K.W. Baran (red.), System prawa pracy, t. 9: Międzynarodowe publiczne prawo pracy. Standardy globalne, Warszawa.

Żołyński J. (2021) Praca w warunkach stwarzających zagrożenie dla życia lub zdrowia pracownika, Gdańsk.

\section{Orzecznictwo}

Orzeczenie Trybunału Konstytucyjnego z dnia 31 stycznia 1996 roku, K 9/95, OTK 1996, nr 1 , poz. 2.

Wyrok ETPC z dnia 26 listopada 2013 roku, skarga nr 37553/05, za: W. Kasprzyk, Prawo do pokojowych zgromadzeń - sytuacja statystyczna państw byłego bloku wschodniego w oparciu o Europejską Konwencję Praw Człowieka, https://repozytorium.uni.wroc.pl/Content/94076/ PDF/03_02_(dostęp: 20 sierpnia 2021).

Wyrok Trybunału Konstytucyjnego z dnia 5 czerwca 2014 roku, K 35/11, OTK ZU 2014, nr 6A, poz. 61.

\section{Akty prawa krajowego}

Konstytucja Rzeczypospolitej Polskiej z dnia 2 kwietnia 1997 roku, Dz.U. 1997, nr 78, poz. 483 z dnia 16 lipca 1997 roku.

Ustawa z dnia 23 maja 1991 roku o rozwiązywaniu sporów zbiorowych, Dz.U. 2020, poz. 123 tekst jedn. $z$ dnia 27 stycznia 2020 roku.

Ustawa z dnia 23 maja 1991 roku o związkach zawodowych, Dz.U. 2019, poz. 263 tekst jedn. $\mathrm{z}$ dnia 12 lutego 2019 roku.

Ustawa z dnia 24 lipca 2015 roku o Radzie Dialogu Społecznego i innych instytucjach dialogu społecznego, Dz.U. 2018, poz. 2232 tekst jedn. z dnia 30 listopada 2018 roku.

\section{Akty prawa międzynarodowego}

Europejska karta społeczna sporządzona w Turynie dnia 18 października 1961 roku, Dz.U. 1999, nr 8, poz. 67. 
Karta Narodów Zjednoczonych, Statut Międzynarodowego Trybunału Sprawiedliwości i Porozumienie ustanawiające Komisję Przygotowawczą Narodów Zjednoczonych, Dz.U. 1947, nr 23, poz. 90.

Karta praw podstawowych Unii Europejskiej, Dz.Urz. UE C 2012, nr 326/391.

Konstytucja Międzynarodowej Organizacji Pracy, Dz.U. 1948, nr 43, poz. 308.

Konwencja nr 87 dotycząca wolności związkowej i ochrony praw związkowych, przyjęta w San Francisco dnia 9 lipca 1948 roku, Dz.U. 1958, nr 29, poz. 125.

Konwencja nr 105 o zniesieniu pracy przymusowej, przyjęta w Genewie dnia 25 czerwca 1957 roku przez Konferencję Ogólną Międzynarodowej Organizacji Pracy, Dz.U. 1959, nr 39, poz. 240.

Konwencja nr 151 Międzynarodowej Organizacji Pracy dotycząca ochrony prawa organizowania się i procedury określania warunków zatrudnienia w służbie publicznej, przyjęta w Genewie dnia 27 czerwca 1978 roku, Dz.U. 1994, nr 22, poz. 78.

Konwencja o ochronie praw człowieka i podstawowych wolności sporządzona w Rzymie dnia 4 listopada 1950 roku, Dz.U. 1993, nr 61, poz. 284 ze zm.

Międzynarodowy pakt praw gospodarczych, społecznych i kulturalnych otwarty do podpisu w Nowym Jorku dnia 19 grudnia 1966 roku, Dz.U. 1977, nr 38, poz. 169.

Międzynarodowy pakt praw obywatelskich i politycznych otwarty do podpisu w Nowym Jorku dnia 19 grudnia 1966 roku, Dz.U. 1977, nr 38, poz. 167.

Powszechna deklaracja praw człowieka z dnia 10 grudnia 1948 roku, Paryż [w:] M.Zubik (red.), Wybór dokumentów prawa międzynarodowego dotyczacego praw człowieka, t. 2, Warszawa 2008. Traktat o Unii Europejskiej, Dz.Urz. UE C 2012, nr 326/13.

Wersja skonsolidowana Traktatu o funkcjonowaniu Unii Europejskiej - Protokoły - Protokół (nr 2) w sprawie stosowania zasad pomocniczości i proporcjonalności, Dz.Urz. UE C 2008, nr 115/01. 